\title{
CALQUING AND METATYPY
}

\section{Malcolm Ross \\ The Australian National University}

\section{Introduction}

I coined the term 'metatypy' a decade ago in Ross (1996), a programmatic article about language contact and the comparative method. In particular, I wanted to characterise a contact phenomenon which had certainly been discussed in the literature but which I felt had not been adequately characterised or clearly distinguished from other contact phenomena. Metatypy is a diachronic process whereby the morphosyntactic constructions of one of the languages of a bilingual speech community are restructured on the model of the constructions of the speakers' other language. I will use Weinreich's (1963: 31) terms 'replica language' and 'model language' for the two languages. The constructions of the replica language are changed through metatypy so as to match those of the model language in meaning and morphosyntax. ${ }^{1}$

The process of metatypy was recognised by scholars long before the term was coined. The classic account concerns the situation at Kupwar, an Indian village on the Indo-Aryan/Dravidian border, where the local varieties of (Indo European) Urdu and (Dravidian) Kannada have undergone radical restructuring on the model of (Indo European) Marathi to the extent that there is morphemefor-morpheme intertranslatability among the three varieties (Gumperz 1969, Gumperz \& Wilson 1971).

I have three goals in this article. The first is to deconstruct my earlier account of metatypy and show that metatypy is preceded chronologically by lexical and grammatical calquing but is separate from these processes. There are thus languages which have undergone widespread grammatical calquing but have stopped short of metatypy. The second goal follows from the first, namely to respond to claims that metatypy is not distinct from previously labelled phenomena like 'grammatical borrowing'. The third goal is to propose a strong hypothesis to the effect that bilingual speakers do not simply copy single constructions from one of their languages piecemeal, but that they restructure the grammar of one language on the model of the other wholesale. This hypothesis is put forward as a basis for research, not as a statement of belief.

Before I address these goals, however, I will provide an example of metatypy.

${ }^{1}$ I would like to thank Anthony Grant and Bernd Heine for their comments on this paper. 


\section{An example of metatypy: Takia}

My example is Takia, an Austronesian language of the Oceanic subgroup spoken on Karkar Island off the north coast of New Guinea (henceforth I employ the common convention whereby 'Oceanic' stands for 'Oceanic Austronesian'). I have used Takia to illustrate metatypy on several occasions (Ross 1996, Ross 2001, Ross 2003), and the reader may wonder why I don't ring the changes by using a different example. The reason is that a proper account of metatypy requires (i) a description of the grammar of the replica language; (ii) evidence of the grammar of that language before it underwent metatypy; and (iii) a description of the grammar of the model language. These conditions are fulfilled by remarkably few accounts of contact-induced change. Point (ii) presupposes that the analyst understands the history of the family to which the language in (i) belongs. Accounts which do fulfil these conditions are few. There are several accounts of IndoEuropean languages. Sasse (1985) narrates how Arvanitic, the Albanian spoken in Greece, underwent lexical and grammatical calquing and syntactic change, increasingly resembling Greek. Haiman (1988) and Denison $(1968,1977,1988)$ describe metatypy respectively in separate RhaetoRomance dialects on the models of Italian and German and in Sauris German in northern Italy on the model of the neighbouring Rhaeto-Romance dialect and of standard Italian. Jones (2002) gives a brief but insightful account of calquing and metatypy on the model of English in Guernsey Norman French, providing frequency data on a number of innovations. Soper (1996) describes metatypy in one Turkic and one Iranian language, each on the model of a language from the other family. Various authors, listed by Harris and Campbell (1995: 124, 142), have investigated the metatypy of Ethiopian Semitic languages on Cushitic models. Aikhenvald $(2002,2003)$ provides a thorough account of grammatical calquing and metatypy in Tariana, an Arawak language, on the model of East Tucanoan languages. Campbell (1987) describes grammatical calquing and metatypy in Pipil, an Uto-Aztecan language, on the model of Spanish. I have only limited expertise in the histories of some branches of western Indo-European and none in the other families involved in these examples, and I therefore prefer to stick to Oceanic Takia. Quite detailed information is available for another Oceanic language which has undergone metatypy. This is Maisin, discussed briefly in Ross (1996: 192-202). I have elected not to discuss it here, as two metatypies can be identified in its history, and their exposition requires a paper to itself.

Takia has undergone metatypy on the model of a (completely unrelated) Papuan language of the Trans-New Guinea (TNG) family. This was probably Waskia, the only other language traditionally spoken on Karkar Island, but there is also lexical evidence of contact with Bargam (otherwise known as Mugil), located around Cape Croisilles on the New Guinea mainland at its nearest approach to Karkar. Published grammatical materials on Takia are Ross (1994b, 2002), whilst Waters, Tuominen and Rehburg (1993) is an unpublished grammar. Waskia is described by Ross (1978), Bargam by Hepner (1986). Crucially, the history of the Oceanic languages of the north coast of New Guinea is reconstructed by Ross (1988: 120-189), and data are available for languages which are quite closely related to Takia but which have not undergone metatypy. These include Ronji (my fieldnotes), spoken on the mainland coast about $100 \mathrm{~km}$ to the southeast of Cape Croisilles, and Arop-Lokep (D'Jernes 1990, 2002). Table 1 provides a rough genealogy of AropLokep, Ronji and Takia. Daughters are indented, e.g. Western Oceanic is a daughter of Proto Oceanic. Sisters share the same indentation, e.g. Ronji and Mato (on one line because very closely related) are sisters of the Bel dialect network. 
Table 1: The genealogy of Arop-Lokep, Ronji and Takia

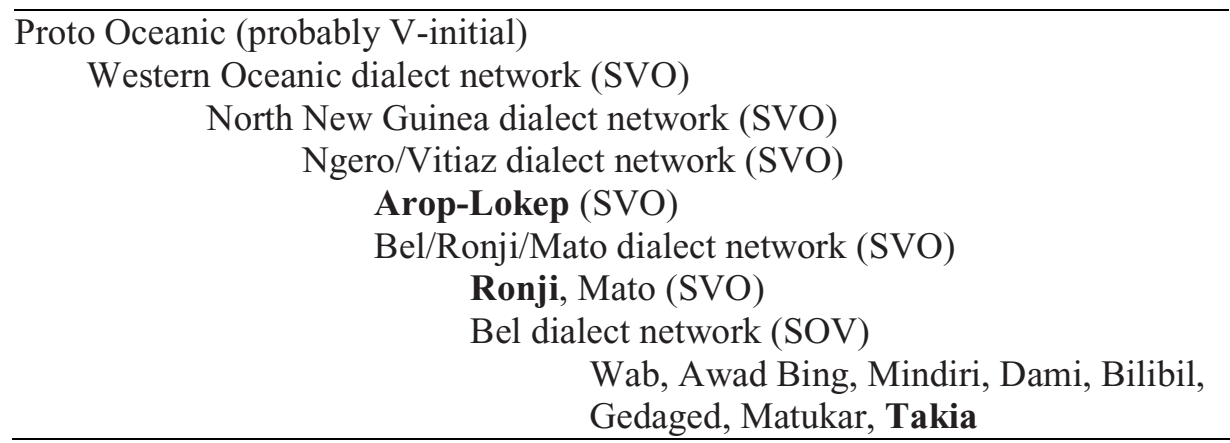

The examples in (1) show transitive clauses in Arop-Lokep, Ronji and Takia.

(1) a. Arop-Lokep:

$$
\begin{array}{lll}
\text { au } & \text { a-kan-a } & \text { pur ata-leu } \\
\text { I } & \text { S:1S-eat-O:3s } & \text { banana one-only } \\
\text { 'I ate just one banana' } & \\
\text { Ronji: } & & \\
\text { ya to } & \text { ya-say } & \text { saula } \\
\text { IRR } & \text { S:1s-eat } & \text { banana }
\end{array}
$$

b. Ronji:

'I shall eat banana'

c. Takia:

$$
\begin{array}{lll}
\text { yai } & \text { fud } & \eta \text {-ani=wa } \\
\text { I } & \text { banana } & \text { s:1s-eat=IRR }
\end{array}
$$

'I shall eat banana'

It is self-evident that Takia morphemes, both lexical and grammatical, have cognates in the other two languages, as shown in (2).

$\begin{array}{lllll}\text { gloss } & \text { 'eat' } & \text { 'banana' } & \text { 'I' } & \text { s:1s } \\ \text { Arop-Lokep } & \text { kan } & \text { pur } & (a u) & (a-) \\ \text { Ronji } & \text { say } & - & \text { ya } & \text { ya- } \\ \text { Takia } & \text { ani } & \text { fud } & \text { yai } & \text { y- }\end{array}$

A little surprisingly, the Arop-Lokep first person singular pronominals (shown in parentheses) are not immediately cognate with Takia $\eta a i$ 'I' or $\eta$ - s:1s. Two sets of first person singular pronouns occur in the Ngero/Vitiaz dialect network, the $\eta$-initial set being innovatory (Ross 1988: 172).

Takia differs from the other two languages in its syntax. Arop-Lokep and Ronji have SVO order, Takia SOV. The Takia irrealis morpheme $w a$ is an enclitic following the verb, but its Ronji counterpart to precedes the verb. All three languages belong to the Oceanic subfamily of Austronesian, for which so much comparative evidence is available that it is certain that AropLokep and Ronji reflect an inherited set of syntactic patterns. Takia syntax, however, is the result of a reshaping on the model of a TNG language, perhaps its TNG neighbour Waskia. This is evident when we compare the Takia and Waskia transitive clauses in (3). ${ }^{2}$

${ }^{2}$ On the history of the Takia construction, see Ross (2001: 142). 
(3) a. Takia:

$\begin{array}{llll}\text { tamo } & \text { an } & \text { yai } & i \text {-fun- } a g=d a \\ \text { man } & \text { DET } & \text { me } & \text { s:3s-hit-o:1s=IMPERF }\end{array}$

'The man is hitting me'

b. Waskia:

$\begin{array}{llll}k a d i & m u & \text { aga } & \text { umo-so } \\ \text { man } & \text { DET } & \text { me } & \text { hit-PR.3S }\end{array}$

'The man is hitting me'

It is not certain that Waskia was the metatypic model for Takia, as one can never be completely certain of the source of a syntactic pattern, and there are plenty of nearby mainland TNG languages with similar syntax. It is reasonably clear, though, that Takia has copied its SOV order from a TNG language. It is also likely that its postverbal aspect/mood enclitics are modeled on the suffixation of verbal markers in TNG languages.

The Takia pattern of NOUN + DETERMINER represented in (3) by tamol an 'the man' probably also reflects restructuring on a TNG model, as Arop-Lokep and Ronji have no determiner, and Oceanic languages typically have a DETERMINER + NOUN construction (Ross 2001: 142).

In (4) Arop-Lokep shows a typically Oceanic possessive noun phrase in which the possessor follows the possessum, whereas Takia displays a reversal of the sequence, following the Waskia model.

(4) a. Arop-Lokep:

rumu ke tool in

house ABL man that

'that man's house'

b. Takia:

Kai $s a-n \quad a b$

Kai CLASS-his house

'Kai's house'

c. Waskia:

Kai ko kawam

Kai ABL house

'Kai's house'

The noun phrases in (5) contain a placename used as an attribute. In Arop-Lokep the possessive construction seen in (4) is used and the placename is possessor, but Takia follows Waskia in simply preposing the placename.

(5) a. Arop-Lokep:

am garup ke Bok

we woman ABL Bok

'we Bok women'

b. Takia:

Waskia tamol an

Waskia man DET

'the Waskia man' 
c. Waskia:

Waskia kadi mu

Waskia man DET

'the Waskia man'

Arop-Lokep is typically Oceanic in forming adjuncts with prepositions, as in (6a), whereas Takia follows the typical TNG pattern and, like Waskia, has postpositions, as in (6b) and (6c).

(6) a. Arop-Lokep:

pay karam

goal bushland

'to the bush'

b. Takia:

Kai sa-n $a b$

lo

Kai CLASS-his house in

'in Kai's house'

c. Waskia:

Kai ko kawam te

Kai abl house in

'in Kai's house'

The conjoined noun phrase in (7a) is formed with the conjunction ma 'and', reflecting an old Oceanic form. The corresponding Takia and Waskia constructions in (7b) and (7c) each contain a postpositional phrase, Takia tamol an ida, Waskia kadi mu ili 'with the man', i.e. the whole phrase in each case means 'I with the man'.

(7) a. Arop-Lokep:

tool tamoto ma rima-na

man male and wife-his

'a man and his wife'

b. Takia:

yai tamol an ida

I man DET with.him

'the man and I'

c. Waskia:

ane kadi mu ili

I man DET with.him

'the man and I'

Although there is usually word-for-word intertranslatability between Takia and Waskia, this does not penetrate below the level of the word. Takia retains its inherited morphological material and word-internal morpheme sequences, as the contrasts between Takia and Waskia verb forms in (3), between possessive morphemes in (4) and (8), and between adjectival plural formatives in (9) show.

(8) a. Arop-Lokep:

Esikel bobo-no

Esikel wife-his

'Esikel's wife'

b. Takia:

Irion tama- $n$

Irion father-her

'Irion's father' 
c. Waskia:

Gambu ko nরu>et

Gambu POSTP «his`father

'Gambu's father'

(9) a. Arop-Lokep:

kai meda-na

tree strong-its

' $\mathrm{a} /$ the strong tree'

b. Takia:

tamol tubu-di en

man big-P:3P this

'this big man'

c. Waskia:

kadi bi-biga amu

man P-big this

'this big man'

A systematic comparison of Takia constructions with their Proto Western Oceanic and Waskia equivalents is given as a tabulation in Ross (2001: 141).

Example (8a) reveals a development in Arop-Lokep to which there will be cause to return below. The Arop-Lokep alienable and inalienable possession constructions differ in their ordering of possessum and possessor. Example (4a) shows possessum-possessor ordering in the alienable construction, but (8a) shows possessor-possessum ordering in the inalienable construction. The latter is an innovation: Oceanic languages typically place the possessor second in both constructions.

The examples above betray no borrowing of phonological forms from Waskia into Takia. A replica language may retain much of its lexicon, and Takia certainly does so, showing regular sound correspondences with other Oceanic languages (Ross 1988: 167-173).

So far, I have shown that Takia speakers have remodelled most of their syntax on Waskia lines. There is, however, another kind of change that apparently reflects contact with Waskia. This is lexical calquing, and it is reflected in word sense, in word compounds and in lexical collocations. Corresponding words, compounds and collocations in both languages have come to have the same ranges of meaning, as in $(10):^{3}$

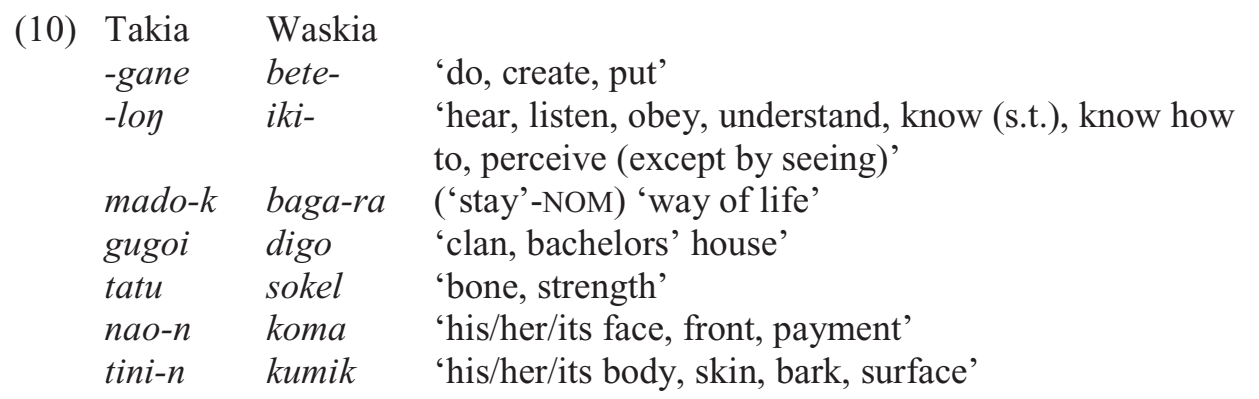

Takia $-n$ and Waskia vowel-rounding (koma < kema; kumik < kimik; cf 8) mark 3s inalienable possessor.

Some calqued word compounds are given in (11):

\footnotetext{
${ }^{3}$ Various authors talk of the same 'polysemies' or 'polysemy patterns'. I avoid these terms because they have technical senses in lexicography.
} 
(11)

'person'
'animal'
'his parents'
'(do) first'

"literal" meaning
'man-woman'
'pig-dog'
'his mother-his father'
'his eye-his eye'

Takia tamol-pein bor-goun

tinan-taman malan-malan
Waskia

kadi-imet

buruk-kasik

nuam-nuet

motam-motam

Listed in (12) are a number of lexical collocations. I use the term 'lexical collocation' for a combination of lexical items that is semantically idiosyncratic (an 'idiom'), i.e. it has a pairing of form and meaning that cannot be predicted from the rest of the grammar. In this respect a lexical collocations is like a lexical item. ${ }^{4}$

\begin{tabular}{|c|c|c|}
\hline 'the palm of my hand' & $\begin{array}{l}\text { Takia } \\
\text { bani-g ate-n }\end{array}$ & $\begin{array}{l}\text { Waskia } \\
\text { a-gitiy gomay }\end{array}$ \\
\hline$=$ 'my hand's liver' & hand-P:1s liver-P:3S & P:1S-hand $<\mathrm{P}: 3 \mathrm{~S}>$ liver \\
\hline '(an) answer’ & ru nao-n & den koma \\
\hline$=$ 'face of word' & word face-P:3s & word $<\mathrm{P}: 3 \mathrm{~S}>$ face \\
\hline 'I am waiting' & mala-g & motam bete-sam \\
\hline$={ }^{\prime} \mathrm{I}$ do/put my eye' & eye-P:1s s:3s-do & \\
\hline ‘I am dizzy’ & mala-६ & motam gerago-so \\
\hline$=$ 'my eye goes round' & eye-P:1s s:3s- & eye go.round-s:3s \\
\hline 'I obey him’ & awa-n ya-ri & kurin karotu-sam \\
\hline$=$ 'I follow his mouth' & mouth-P:3s s:1s-follow & $<\mathrm{P}: 3 \mathrm{~s}>$ mouth follo \\
\hline 'I disobey him' & $a w a-n \eta u-t$ & kuriy batugar-sa \\
\hline$=$ 'I cut his mouth' & mouth-P:3 & buth cu \\
\hline 'I exclude him' & $n a o-n \eta u-f u$ & alo-sam \\
\hline$=$ 'I fence off his face' & face-P:3s s:1s-fence.off & $<\mathrm{p}: 3 \mathrm{~s}>$ face fence.off-s: \\
\hline 'I correct him' & kukuc & dogowa ilu-sam \\
\hline$=$ 'I hold his ear' & ear-P:3s s:1s-hold & $<\mathrm{p}: 3 \mathrm{~s}>$ ear hold-s: $1 \mathrm{~s}$ \\
\hline 'I am thinking' & kank & kuamin tugu-sam \\
\hline$=$ 'I put thought' & thought S:1S-put & thought put-S: $1 \mathrm{~S}$ \\
\hline 'He believes (it)’ & ilo-n & 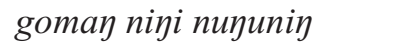 \\
\hline$=$ '(it is a) truth in his guts' & $\begin{array}{l}\text { inside-P:3S POSTP:in } \\
\text { truth }\end{array}$ & $<\mathrm{P}: 3 \mathrm{~S}>$ liver POSTP:in tru \\
\hline 'I am angry' & ilo-g saen & a-gemay memek \\
\hline 'my guts are bad' & inside-1SG bad & 1SG-liver bad \\
\hline
\end{tabular}

Closely related to lexical calquing is what we may call 'grammatical calquing'. Lexical calquing consists of remodelling lexical 'ways of saying things' on the model of Waskia. That is, the meaning range of each lexical item is matched to the meaning range of an item in the model language until the two vocabularies are readily intertranslatable. Similarly, grammatical calquing consists of remodelling grammatical 'ways of saying things' on the metatypic model. The most obvious case of grammatical calquing in Takia is its postpositions, shown in (13).

\footnotetext{
${ }^{4}$ Examples of lexical collocations can easily be multiplied, but I have eliminated any with Tok Pisin translation equivalents, as the latter could be a source of Takia-Waskia equivalences or, more probably, could reflect areal idioms.
} 
(13)

$\begin{array}{lll} & \text { Takia } & \text { Waskia } \\ \text { location } & \text { na, te } & \text { se, te, } i \\ \text { location 'in' } & \text { lo } & \text { nuyi } \\ \text { location 'on' } & \text { fo, fufo } & \text { kuali } \\ \text { ablative } & - & \text { ko } \\ \text { instrument } & \text { nam (=na-mi) } & \text { se } \\ \text { referential } & o & \text { ko } \\ \text { manner } & m i & \text { wam } \\ \text { accompaniment } & d a & \text { karo }\end{array}$

Here I am concerned with the semantic reorganisation of the adpositional system, not with the syntactic change from preposition to postposition. Most Oceanic languages have a very small stock of adpositions (Ross 2003c, Forthcoming). Takia speakers have remodelled their adpositional system on the Waskia model. In this particular case, at least, remodelling has entailed the creation of new items rather than changing the meaning ranges of old ones. For a reconstruction of the history of $l o$ 'in' and fo and fufo 'on', see Ross (1996: 189-190 or 2001: 143).

The Takia postposition paradigm matches the Waskia almost completely. Only the Waskia ablative postposition has no Takia equivalent. A major function of Waskia ko is to mark the possessor, as in (4) (8), and Takia does this with inherited bound morphology, so this difference is perhaps not surprising.

What (13) cannot show is the quite exact parallels between Takia lo 'in' and Waskia numi 'in' and between Takia fo, fufo 'on' and Waskia kuali 'on'. Both languages regularly use an inalienably possessed relational noun with the construction in (8) in a postpositional phrase like those in (14) to express certain intrinsic locations:

(14) a. Takia:

ab nao-n na

house face-its at

'in front of the house'

b. Waskia:

kawam koma se

house its.face at

'in front of the house'

Takia lo 'in' and fo, fufo 'on' and Waskia nuyi 'in' and kuali 'on' represent grammaticisations of relational nouns. The final $-i$ of Waskia nuyi and kuali reflects the postposition $i$, and the roots apparently reflect earlier third person forms ('its inside', 'its top') of the now lost relational nouns

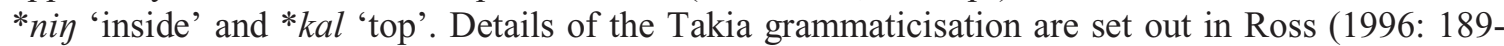
190, 2001: 143). Suffice it to say here that the Takia postpositions lo and [fu]fo are transparently cognate with the inalienable possessed Arop-Lokep relational nouns lo- 'inside' and po- 'top (surface)' in (15).

(15) Arop-Lokep:

a. rumu lo-no

house inside-its

'(the) inside (of) the house'

b. katakata po-no

shelf top-its

'on (the top of) the shelf' 
I noted above that Arop-Lokep is innovatory in its possessor-possessum order. This order was crucial to the reanalysis of the possessum relational nouns as the postpositions in Takia phrases like $a b l o$ 'in the house' and $a b$ fo 'on (top of ) the house'.

\section{Redefining metatypy}

The term 'metatypy' labels the diachronic process briefly illustrated in examples (1) to (9) for Takia: the diachronic process whereby the morphosyntactic constructions of one of the languages of a bilingual speech community are restructured on the model of the constructions of the speakers' other language, such that the constructions of the replica language come to more closely match those of the model language in both meaning and morphosyntax. Metatypy means 'change in type' (cf the geological term metamorphy 'change in form'), where 'type' is used in the sense implicit in the term 'typology': SOV and SVO are clause 'types', NOUN + DETERMINER and DETERMINER + NOUN are noun phrase 'types', and so on.

However, my original definition (Ross 1996), also assumed in subsequent papers (Ross 1997, 2001, 2003a) was wider than this. Contact-induced morphosyntactic restructuring like that in Takia and the languages named earlier is apparently always preceded by lexical and grammatical calquing (Sass 1985: 75, Ross 2001:146), i.e. they are preconditions of morphosyntactic restructuring. Hence I lumped calquing and grammatical restructuring together under the rubric 'metatypy'. In Ross(2006) I narrowed the definition of metatypy to label only the restructuring process itself. The main reason for this is that we find languages where lexical and grammatical calquing has occurred, but little or no syntactic restructuring. I have been tempted to say in the past that they had undergone a measure of metatypy, but it is simpler to say that they have undergone calquing but not metatypy.

An example of such a language is the Mixe dialect of Basque spoken in French Lower Navarre and described by Haase (1992). It displays extensive grammatical calquing on the model of Gascon, but only very limited morphosyntactic restructuring.

\subsection{Mixe Basque}

A good deal of Haase's material has to do with the case marking system. Because Basque, as conventionally described, has fourteen cases (Haase 1992: 62), all marked by suffixes. Eight of them can be regarded as 'basic' and six as 'secondary', in that they are morphologically more complex than the basic cases and share certain component forms. Gascon, like other western Romance languages, has no bound case markers; it has a set of prepositions. Calquing has resulted as speakers have sought Basque translation equivalents of Gascon expressions.

One instance concerns a basic case, the instrumental. Its earlier use is illustrated in (16a) from an eighteenth-century text. In more recent Mixe Basque, the instrumental has been largely replaced by the comitative, as in (16b), but the instrumental survives in lexicalised expressions like oin-ez (footINSTR) 'on foot' (Haase 1992: 67).

(16) a. Ginco-a-c ber-e huntarçun-ez bethe, eta ber-e dohain-ez God-ART-ERG same-GEN goodness-INSTR full and same-GEN grace-INSTR aberas-tu thi-ela. rich-PARTIC PRES(ABS:3P)(ERG:3S)-SUBORD

'God made them full with His goodness and rich with His grace' (Haase 1992: 71)

b. koller bat-ekilan

spoon one-COM

'with a spoon' (Haase 1992: 67)

The key to understanding what has happened here is simple. Gascon, like many west European languages, uses the same preposition to express the instrument and the comitative (cf. English with), 
and Basque speakers have imitated this pattern by extending the comitative case to cover the instrumental function (Haase 1992: 67).

Historically, the translation equivalence probably goes further than this. The earlier comitative form was apparently -eki. Since the sixteenth century the complex case forms -ekila or -ekilan have displaced it. They include -la 'allative' and $-n$ 'locative'. The Gascon forms have undergone parallel complexification. The original instrumental/comitative preposition was $a b$ ( $<$ Latin $a p u d)$; it is now minimally dab, from de 'genitive' $+a b$ 'instrumental/comitative' (Haase 1992: 78-79).

A second Mixe Basque case conflation is the replacement of the ablative case-marker by the partitive case-marker. Thus the traditional form in (17b) is replaced by the partitive in (17a) (Haase 1992: 72-73). ${ }^{5}$

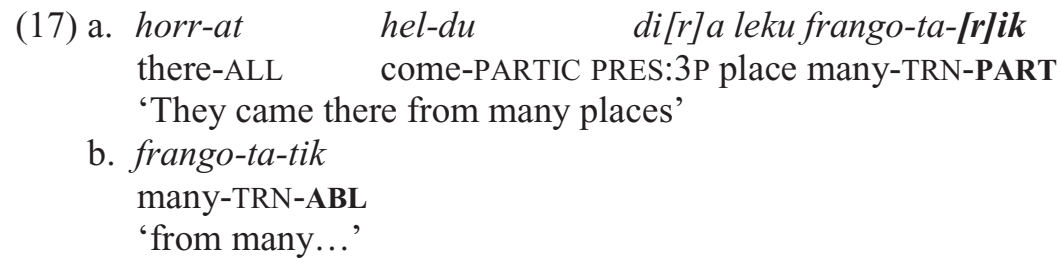

This change also has a simple explanation: in Gascon (and French), both the partitive and ablative functions are carried by the preposition $d e$.

Finally, (Haase 1992: 80) lists instances where Mixe Basque has calqued Gascon 'complex locational prepositions', i.e. collocations derived from an earlier sequence of [PREPOSITION ${ }_{l}+$ ] RELATIONAL NOUN + PREPOSITION $_{2}$. The calqued construction in Mixe is CASE-MARKER $2+$ RELATIONAL NOUN [+ CASE-MARKER ${ }_{l}$ ]. The sequences in (18) show near translation equivalence. Gascon forms with initial locative preposition au have Mixe equivalents with the final locative casemarker - [e]an. Gascon forms with final genitive de have Mixe equivalents with an initial genitive case-marker. Gascon forms with a final dative/allative a have Mixe equivalents with an initial dative or allative case-marker.

\begin{tabular}{|c|c|}
\hline Gascon & $\begin{array}{l}\text { Mixe Basque } \\
\text { au darrèr de }\end{array}$ \\
\hline 'in front of' & au davant de \\
\hline 'between' & entermiei de \\
\hline 'towards, in the direction of' & [de] cap a \\
\hline 'as far as' & $\operatorname{dinc} a$ \\
\hline 'near, beside' & acostat a \\
\hline
\end{tabular}

GEN gibel-ean
GEN aintzin-ean
GEN arte-an
DAT/ALL bu[r]uz
[ALL] artio
DAT hurbil

The process of translation equivalence has evidently been going on for a long time. The form in (19a) is common Basque, and the case-marked form in (19b) is also ancient. However, the form in (19c), with a dative, occurs only in Mixe Basque, and evidently represents the most recent stage of calquing (Haase 1992: 79-80).

(19) a. eliza aintzin-ean church front-LOC 'in front of the church'

b. eliza-[r]en aintzin-ean church-GEN front-LOC 'in front of the church'

\footnotetext{
${ }^{5}$ The abbreviation TRN means 'transnumeral', i.e. a form which may be either singular or plural. 


\section{c. eliza-ri hurbil \\ church-DAT near \\ 'in front of the church'}

A striking Mixe grammatical calque is the innovation of a passive to match the Gascon passive. Other Basque dialects have no passive. The Mixe passive is formed from the resultative, which marks a state as relevant at a discourse-related point of time. ${ }^{6}$ The resultative is formed with the combination PARTICIPLE-ARTICLE + AUXILIARY (Haase 1992: 96), as in (20a) and (20b), where the verbs are transitive and intransitive respectively. ${ }^{7}$ The Mixe passive is formed by adding the participle of the verb 'be' before the intransitive auxiliary, as in (20c). Finally, the agent, if any, is expressed by a noun phrase in the partitive case, as in (20d). We might expect to find the ablative case here, but I noted above that the partitive has displaced the ablative, and corresponds to the Gascon preposition de (which, along with per, marks the agent of a Gascon passive).

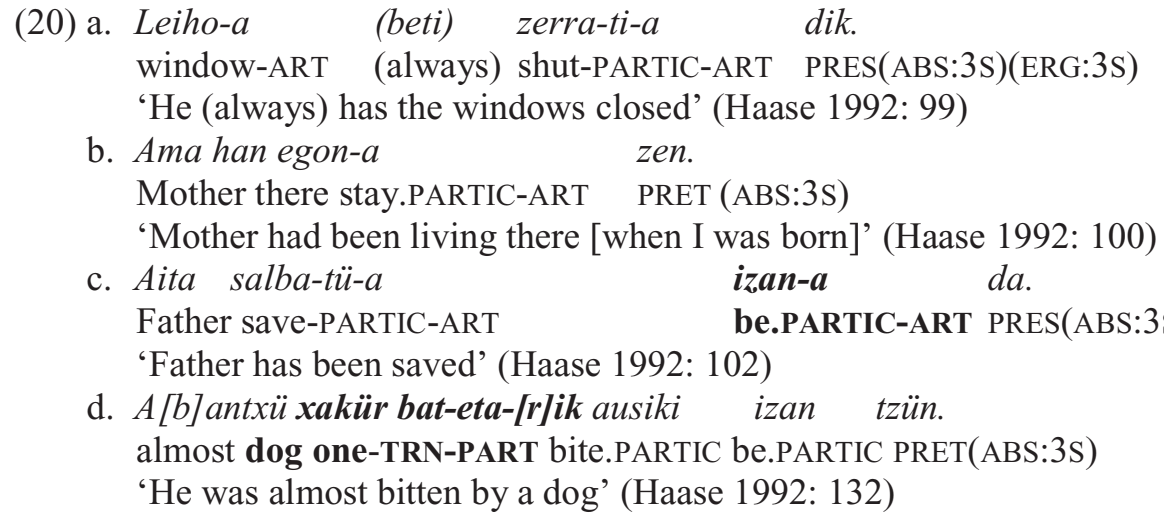

As Haase (1992: 101) points out, this is a calque, an attempt at translation. His comparison of the Mixe and French constructions is shown in (21). What is clear is that this is part of the reorganisation of the language's semantic patterns and 'ways of saying things. It does not, however, entail a full-scale restructuring of the syntax of the construction. The addition of izan, the participle of 'be', represents a structural change, but its sequential order is determined by the existing Basque construction that places an auxiliary after the main verb. As the subscripts in (21) show, there has been no adoption of Romance constituent order. This is even clearer in (20d), where the agent phrase precedes the verbal complex: in a Romance passive it would normally follow it.
(21) a. Etxe- $a_{1}$
etz $\ddot{u}_{2} \quad$ destrüiti- $a_{3}$
$\operatorname{izan}_{4}$.
house-ART
NEG.PRES(ABS:3s) destroy.PARTIC-ART
be.PARTIC

'The house has not been destroyed.'

b. [La maison $]_{1}$ [n' a pas $]_{2}$ été 4 détruite 3 .

ART house $\mathrm{NEG}_{1}$ have $\mathrm{NEG}_{2}$ be-PARTIC destroy.PARTIC

'The house has not been destroyed' (Haase 1992: 101)

\footnotetext{
${ }^{6}$ The resultative may itself be the outcome of earlier grammatical calquing, but that is another story (Haase 1992: 96-100).

${ }^{7}$ A complexity of the Basque auxiliary is that it has alternant forms according to the status and gender of one's addressee: dik is masculine singular familiar.

${ }^{8}$ It is a pity (i) that the comparison is with French rather than with Gascon and (ii) that the example sentence is negative, unlike the passives in (20c) and (20d).
} 
The instances of grammatical calquing illustrated in (18) and (21), i.e. complex 'adpositions' and the passive, differ from the calquing of simple postpositions in both Takia and Mixe Basque in a significant respect. The calquing of postpositions affects single-morpheme items, i.e. it resembles lexical calquing but affects a closed class of morphemes. In the Mixe calques illustrated in (18) and (21), however, it is not a single morpheme that is calqued, but a complex item composed of a morpheme sequence. I regard this nonetheless as grammatical calquing, not as metatypy, as it embodies changes in categories and their memberships (thus the Mixe passive represents the creation of a category 'voice' to match Gascon voice), not change in syntax.

Thus calquing has occurred in Mixe Basque, but not metatypy. Another language of which this appears to be true is Maltese (Drewes 1994). Calquing may be a necessary precondition of metatypy, but it is not necessarily followed by metatypy. Whether there are conditions which might enable us to predict when metatypy might occur, I am not sure, but the example in $\S 3.2$ points us toward the relationship between grammatical calquing and metatypy in $\S 3.3$ and perhaps in the direction of an answer.

\subsection{Imitating, not borrowing}

From the examples in $\S 2$ it would seem that Takia has copied its syntax directly from Waskia, but a little thought indicates that this cannot be true. First, metatypy has preceded by massive calquing. Secondly, metatypy itself must have been a gradual process during which a good deal of variation occurred. Third, recall that the passive in Mixe Basque has arisen not by direct copying from Gascon but by the adaptation and expansion of an existing Basque construction to imitate the Gascon passive. In her analysis of the rise of the Yiddish dos-sentence, a focus construction, Prince (1998: 340-346) shows that speakers of eastern Yiddish imitated a Slavic construction, but did not borrow it.

Yiddish is a language of European Jews. It is descended from a mediaeval dialect (or dialects) of High German, but for centuries eastern Yiddish speakers were out of contact with other Germanic languages, lived among Slavic speakers and were bilingual in the local Slavic communalect. This led to metatypic changes in eastern Yiddish on Slavic models. One outcome is that eastern Yiddish has a focus construction with no correspondent in any Germanic communalect nor in mediaeval western Yiddish. The dos-sentence is illustrated in (22), and, as the free English gloss indicates, its function in this example is similar to that of an English it-cleft, i.e. it places the subject Leyb in focus, excluding the verb from focus (examples are from Prince 1998).

$$
\begin{array}{lll}
\text { Eastern Yiddish: } & & \\
\text { dos hot Leyb } & \text { gezen } & \text { Eriken } \\
\text { that has L. } & \text { seen } & \text { E.:ACC } \\
\text { 'It's Leyb who saw Erika' } &
\end{array}
$$

The model for this was evidently a Slavic construction illustrated in the Russian sentence in

$$
\begin{aligned}
& \text { Russian: } \\
& \text { èto Leonid uvidel Eriku } \\
& \text { that L. saw E.:ACC } \\
& \text { 'It's Leonid who saw Erika' }
\end{aligned}
$$

Unlike the English translation, neither of the two constructions is a cleft. However, Prince (1998) points out that there are important differences between them. In Russian, the object can also occupy the focus position immediately after èto, giving: 
(24)

Russian:
èto Eriku Leonid uvidel
that E.:ACC L. saw
'It's Erika that Leonid saw'

Informally, one may say that the Russian construction is like an it-cleft, in which èto corresponds to $i t$, but with the relative pronoun omitted.

Despite the superficial similarity between (22) and (23), however, the Yiddish dos-construction does not allow a permutation corresponding to (24). In fact the Yiddish correspondent of (24) is not * dos Eriken hot Leyb gezen but dos hot Leyb gezen ERIKEN, with pitch accent on ERIKEN. In other words, initial dos 'that' plus AUXILIARY + SUBJECT sequence (reversal of unmarked SUBJECT + AUXILIARY) has come to mark the NP-focus construction, whereas in Russian it is marked by èto 'that' plus the focused NP.

Prince suggests that the basis for the dos-construction in (22) was the zero-topic (detopicalising) German/Yiddish es-construction in (25), which is used as a sentence-focus construction answering 'What happened? ' when the subject referent is not topical.

$$
\begin{aligned}
& \text { Eastern Yiddish: } \\
& \text { es hot Leyb gezen Eriken } \\
& \text { it has L. seen E.:ACC } \\
& \text { 'It happened that Leyb saw Erika' }
\end{aligned}
$$

Yiddish-speakers equated this syntactically with the subject-focus version of the Russian èto construction in (23) but adapted it, replacing es with dos, the Yiddish translation equivalent of Russian èto, and using the adapted construction as the equivalent of the Russian èto focus construction. However, the syntax of the new (dos) construction remained that of the es construction, obstructing the fronting of a focussed object that occurs in Russian (24).

One might ask, incidentally, why Yiddish speakers 'needed' this construction. Medieval Yiddish presumably had the German fronted focus construction as in the following manufactured hypothetical examples:

$$
\begin{aligned}
& \text { a. Leyb hot gezen Eriken } \\
& \text { L. has seen E.:ACC } \\
& \text { '(It's) Leyb (who) saw Erika' } \\
& \text { b. Eastern Yiddish: } \\
& \text { Eriken hot Leyb gezen } \\
& \text { E.:ACC has L. seen } \\
& \text { 'It's Erika that Leyb saw' }
\end{aligned}
$$

However, in (26a) a focus subject is differentiated from a non-focus subject only by intonation, and in both sentences only intonation differentiates between (fronted) topic and (fronted) focus. Later on, isolated from German, a construction emerged which made these distinctions syntactically on the Slavic model, and it did so by the adaptation of an existing Yiddish construction which was superfically similar to the Slavic NP focus construction.

This shows that metatypy does not necessarily consist of the direct copying of a construction. Rather, it may consist in speakers expressing a particular constructional meaning by using a construction which they equate with the construction in the model language. They may find a readymade construction in the replica language and extend or change its constructional meaning to the meaning of the model language construction, as in the case of 'Yinglish' Yiddish movement, also described by Prince (1998). ${ }^{9}$ Or they may adapt an existing construction in the direction of the

9 'Yinglish' is a Yiddish-influenced English variety used by Jews in New York City. 
model language construction, as in the case of the Yiddish dos construction. Either way, metatypy is imitation rather than direct copying. This point is made forcibly by Heine \& Kuteva (2005: 7, 34$37,81)$.

One might argue that creation of the Yiddish dos construction more closely resembles the creation of the Mixe Basque passive than the metatypic syntactic reorderings of Takia, since both the Yiddish and Mixe constructions are calques on a construction in the model language created by adapting an existing construction. The next section is a brief examination of this issue.

\subsection{The relationship between grammatical calquing and metatypy}

The Yiddish example in $\$ 3.2$ suggests that the boundary between grammatical calquing and metatypy may not be so easy to draw as I have implied up to this point. In the instance of the Mixe passive in $\S 3.1$, we can say that we are dealing with calquing, not with metatypy, because there has been no syntactic reordering. In the instance of the Yiddish dos construction, this decision is not so easy. Prince's analysis shows that we are dealing with grammatical calquing, but the outcome looks like metatypy, because the ordering of elements in (22) and (23) is the same. But the correspondence only applies if the focussed noun phrase is the subject. If it is the object, the difference between the constructions in the two languages emerges. On the basis of metatypy in Takia, one might argue further that the stage I have labelled 'metatypy' could only be said to have occurred if there were a syntactic change in Yiddish which allowed its speakers to say the impossible *Dos Eriken hot Leyb gezen 'It's Erika that Leonid saw.'

The Takia grammaticisation of relational nouns as postpositions presented in $\S 2$ also presents a problem if we try to specify where calquing ends and metatypy begins. This grammaticisation is an obvious case of calquing, but it was only possible because the switch from possessum-possessor order in inalienable possessive noun phrases to possessor-possessum order had occurred earlier - in a language ancestral to both Arop-Lokep and Takia (cf. Table 1). Since this switch very probably occurred as a result of contact with TNG languages, one might say that metatypy had begun in a language ancestral to Takia long before the calquing of postpositions took place.

This suggests - unsurprisingly - that the border between grammatical calquing and metatypy is a fuzzy one. If calquing results in constructions that look syntactically like those of the model language, then the basis has already been laid for metatypy (and in a sense, metatypy has already begun). This observation also has an obverse. If there are substantial structural differences between the two languages, as there are between Basque and Gascon, then new constructions resulting from calquing (like the Mixe passive) are still too different syntactically from the model construction (the Gascon passive) to provide a foundation for metatypy. In other words, the more profound the morphosyntactic differences between the calquing language and the model language, the less likely metatypy is to occur. ${ }^{10}$ But this is a hypothesis which needs a good deal of further research (for discussion, see Harris \& Campbell 1995:123-127).

Does the Yiddish story cast any light on Takia metatypy? We know that one of the most general constructions in the language, the SVO order of non-imperative clauses, was changed to SOV. Can we explain how this happened? Can we reconstruct constructions at the SVO stage which speakers might have matched with the SOV construction of their Papuan inter-community language and used as the basis for their own SOV construction? I believe we can.

Western Oceanic languages typically coreference the person and number of their subject with a verbal proclitic or prefix, as illustrated in (1), (3a) and (12). Human objects, at least, are coreferenced with a verbal enclitic or a suffix, as in (3a). This means that many clauses consist only of the verb word. Where noun phrases occur, it is typically at the rate of one per clause. If that noun

\footnotetext{
${ }^{10}$ The converse case would be that the syntax of the two languages is so similar that there is very little scope for metatypy after calquing. Molisian Slav, a Croatian dialect spoken in southern Italy described by Breu in a number of publications (e.g. Breu 2003, Breu 2003a), is perhaps an example.
} 
phrase is an object, then in an SVO language the default order is VO. However, many SVO Oceanic languages may front the object if it is a newly introduced or re-introduced referent. Since there is a strong tendency to introduce new referents in object position, this means that in practice OV sequences may occur quite frequently. In the following Takia example from a narrative in which the speaker recounts how he came to be paraplegic, we have a sequence of clauses where the only noun phrases are objects:

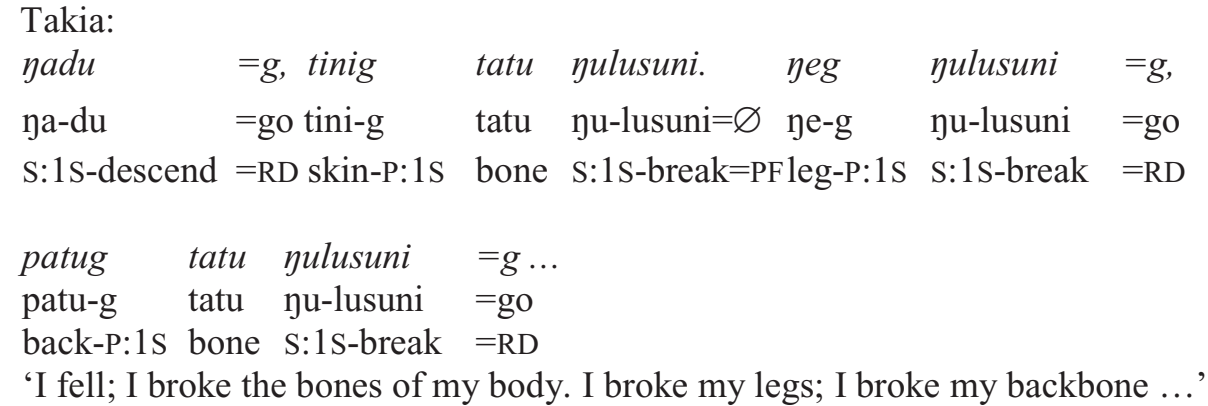

Takia, of course, has SOV order. But it is easy to see that this story could have been told in an SVO language with each object fronted because it introduces a new referent. It is also not difficult to perceive how speakers could have taken the fronted object construction and extended its use, probably with a change of intonation pattern, so that it became the general non-imperative construction. This, of course, would account for OV and SV clauses, the vast majority of clauses in which noun phrases appear. It does not account directly for much lower-frequency SOV clauses, and we must assume that they emerged at a stage by which neither OV nor SV clauses represented a special focus or topicalisation construction.

The short passage in (27) also illustrates a piece of grammatical calquing in Takia. Takia has imitated from TNG languages the strategy of chaining clauses that occur in temporal and certain other sequences in what Foley (1986: 175-205) calls a coordinate-dependent relationship, whereby each clause ends with a dependent enclitic specifying mood, in this example the realis dependent (RD) enclitic $=g o$. The full specification of tense and aspect is provided by the sentence-final enclitic on the final clause (this Takia system is described by Ross 1994b). What is noteworthy here is that the dependent enclitics $=g o$ 'realis' and $=p e$ 'irrealis' both reflect what were once conjunctions, but these acquired a more constrained function when Takia calqued the coordinatedependent VS independent distinction on a TNG model. For a detailed account, see Ross (1987).

\subsection{Notes on the social parameters of metatypy}

In Ross (1996, 2001, 2003) I also gave a social criterion for metatypy: I wrote that in a bilingual community, the language undergoing metatypy would be the language which was emblematic of its speakers' identity and the metatypic model would be the language used to communicate with people outside the speech community. This is true of the majority of cases I know of, but not of all. Sometimes the social relationship between the languages is the converse: the language undergoing metatypy is the inter-community language and the metatypic model is its speakers' emblematic language. This point was made briefly in Ross (2006), and was taken up independently by Bowden (2005) in a paper which shows how the extensive directional system of the lingua franca North Maluku Malay has been calqued and has undergone a measure of syntactic restructuring on the model of the directional systems of the Austronesian and Papuan languages of the North Maluku area (Halmahera and its offshore islands). The result is a system in North Maluku Malay which is incomprehensible to speakers of standard Indonesian (itself a Malay lect) or of other colloquial Malay dialects. The phonological forms are often similar, but the meanings are very different. 
Other inter-community languages that have undergone metatypy are 'Singlish' (basilectal Singapore English; Platt 1975) and Taiwan Mandarin (Chappell 2001). The key in these cases and in the case of North Maluku Malay is that these are spoken in speech communities where speakers of the emblematic language(s) are a significant majority and where a variety of the inter-community language is used at least as much for communication among those speakers as it is for communication with speakers of another language or of other languages.

A separate issue is raised by Thomason \& Kaufman's (1988: 117, 135-139) account of changes in the Dardic Indo-Aryan language Shina of Pakistan. Thomason \& Kaufman, basing themselves on Lorimer (1937), outline a set of changes which look remarkably parallel to those that have occurred in Takia. There has at least been substantial lexical and grammatical calquing, if not metatypy. Lorimer's data do not allow us to decide regarding metatypy, but the few sentence examples indicate word-for-word intertranslatability. Indeed, the Shina features that Thomason \& Kaufman discuss are not inherited from Proto Indo-Aryan but are found in neighbouring Burushaski, an isolate. Thus Shina appears to have undergone calquing and perhaps metatypy on the model of Burushaski. However, Thomason \& Kaufman assert several times that the Shina features reflect shift to Shina by Burushaski speakers. They write:

The argument that the mechanism of interference was shift can be disputed; but we find Lorimer's discussion of this point cogent, and the fact that the relevant grammatical morphemes themselves are native to Shina suggests interference through shift rather than borrowing. (Thomason \& Kaufman 1988: 139)

The fact that the grammatical morphemes are native to Shina implies that Shina has changed on the model of Burushaski, not that Burushaski speakers have shifted to Shina. It is true that Lorimer (1937: 69) suggests that shift may have occurred, but on the next page he remarks that probably all Shina-speaking men can speak Burushaski (and that the two communities intermarry). This provides an ideal situation for calquing and metatypy.

In fact it is clear from other cases cited in the same section of Thomason \& Kaufman (1988) that they regard grammatical calquing as a feature that reflects language shift. This seems to me to be wrong. In many, perhaps most, cases of shift, the shifting speakers acquire their new language perfectly, and almost no linguistic traces of shift persist. Occasionally, a community of shifting speakers will learn their target language imperfectly and be prevented by circumstances from completing the shift, in the sense that they will retain their 'imperfect' version of the target. One of these rare cases appears to be Madak, an Oceanic language spoken in the isolated uplands of central New Ireland (Ross1994a). The shifting speakers previously spoke the Papuan language Kuot (or something very like it) and, not unnaturally, took their phonology with them when they learned their new Oceanic language. Kuot phonology has significant effects across word boundaries within the phonological phrase, and these are also reflected in Oceanic Madak in ways that distinguish it sharply from neighbouring Oceanic languages.

The effects of shift are thus very different from those of metatypy (Ross 2003a), and Shina manifests outcomes diagnostic of metatypy on the model of Burushaski, not of shift.

\section{Metatypy as a distinct kind of contact-induced change}

There is an emerging paradigm of types of contact-induced change, based on the inference that social conditions constrain the linguistic outcomes of contact (Thomason \& Kaufman 1988, Ross 1997, 2003a). Metatypy is one outcome. Language shift, pidginization and language mixing are others.

My concern here is not with this uncontroversial statement, but with the question of whether the term 'metatypy' is necessary. It has been suggested by some that it is simply a new label for an already recognised and labelled phenomenon. My response is that the phenomenon has indeed been 
recognised, but it has not been labelled in a way that distinguishes it clearly from other contact phenomena.

I have exemplified the effects of metatypy in $\S 2$, but I have referred only obliquely to what brings it about. Nadkarni (1975: 681) wrote:

Bilingualism is, after all, a psychological load - not so much because it requires knowing two language systems, but because, in a situation of intensive bilingualism, one is called upon to conduct communication through these two distinct systems all the time, using now one system and now the other. In such a situation, the tendency towards lessening the psychological load is quite natural; and this sets processes in motion whose result is a gradual convergence of systems in a speaker's head. Among the factors which determine the direction of this convergence, the frequency with which the two languages are used may be one of the most important.

Sasse (1985: 84-85, 1990: 32) writes that lexical calquing, grammatical calquing and syntactic restructuring share a single cause: bilingual speakers' need to express the same thoughts in two languages. Haase (1992: 166-168) talks similarly of a push towards 'translation equivalence'. This means that lexical calquing occurs as speakers reorganise the lexicon of one of their languages to match the semantic organisation of the other, with outcomes like those illustrated in (10). This reorganisation extends to closed categories, so that grammatical calquing brings about a match between the categories of the two languages and the memberships of these categories. Prince attributes constructional imitation (\$3.2) to the fact that "Speakers of a language may borrow the meaning - semantic or pragmatic - associated with some form in a contact language/dialect and associate it with some form found to be analogous in their own language..." (Prince 1998: 339). As I observed in $\$ 3.3$, a precise boundary between grammatical calquing and metatypy can probably not be drawn, but there is nonetheless a progression from the former to the latter. If we accept that the syntactic constructions of a language are, like lexical items, form-meaning pairings, but pairings in which he encoded meaning is quite abstract, then the sequence lexical calquing $>$ grammatical calquing $>$ metatypy is one in which constructions which express increasingly abstract meanings come to be organised similarly across the two languages.

If this characterisation is correct, then lexical and grammatical calquing and metatypy are processes which affect the whole language. The literature on language contact, however, is loaded with instances in which a single construction has supposedly been borrowed from one language into another, e.g. the borrowing of relative clause constructions and from various Indo-Aryan languages into various Dravidian languages in Sridhar (1978: 204-205) (one of the latter is Gondi, cited by Thomason \& Kaufman 1988: 139) and from Dravidian Kannada into Indo-Aryan Konkani in Appel \& Muysken (1987: 158-159). A proper assessment of these instances requires a good deal more research into the relevant languages, looking at the history of each grammatical system as a whole, including complicating factor that some of these innovations are literary devices Sridhar (1978: 200). Although Appel \& Muysken's source, Nadkarni (1975), focusses on the borrowing by Konkani speakers of an additional relative clause strategy, he is at pains to show that this is part of an ongoing process. Ironically, the construction which Indo-Aryan Konkani is now borrowing from Dravidian Kannada had been borrowed by Kannada from an Indo-Aryan language sometime around the tenth century. Before that time, Kannada had employed only participial relativisation, a construction which has also been borrowed into Konkani (Nadkarni 1975: 674-675). Nadkarni comments that both languages are part of Emeneau's (1956) Indian linguistic area and are syntactically similar, and his sentence examples show word-for-word (and apparently morphemefor-morpheme) intertranslatability. This suggests that the 'borrowing' of the relative clause structure may represent a late instalment in a long story of metatypy, the more so in the light of the quotation from Nadkarni above.

Whether bilingual speakers do borrow constructions piecemeal is a question which I think has yet to be convincingly answered (see $\S 5$ ). In other words, I think it likely that anecdotal accounts of 
the borrowing of a single construction may in many cases represent only the tip of an iceberg: careful investigation might reveal that the borrowed construction was simply one among many (or that the bilingual community's two languages already had so many similar constructions that borrowing was unnecessary).

I have used the term 'borrowing' in the previous paragraph, as terms like 'grammatical borrowing', 'syntactic borrowing' and 'structural borrowing' are often used in the contact literature, e.g. by Emeneau (1962), Appel \& Muysken (1987: 158-162), Thomason \& Kaufman (1988: 67) and King (2000). However, these terms are inappropriate for three reasons. First, 'borrowing' implies copying of individual constructions, whereas, as I noted above, I take metatypy to be a wholelanguage process. ${ }^{11}$ This point is made by Soper (1996: 295). Second, when a construction is 'copied' from one language into another, it is not just structure that is copied, but a pairing of structure and meaning. Third, Prince's (1998) study of the restructuring of Eastern Yiddish on Slavic models shows that speakers do not necessarily (and perhaps do not usually) 'borrow' constructions wholesale, but instead adapt existing constructions to imitate those of the model language. Johanson (2002: 288) remarks, "The term "borrowing" is...based on a deceptive metaphor."

One rather neat label is 'isogrammatism', coined by Gołą (1959) to label a pairing of corresponding and similar grammatical constructions in two Balkan languages. Insofar as it labels the result of a historical process, not of the process itself, 'isogrammatism' is preferable to 'borrowing', but again it labels a single construction, not a system-wide process. Gołąb discusses only Balkan data, and so by default 'isogrammatism' labels an outcome of metatypy. We do not know how he would have labelled a grammatical calque. ${ }^{12}$

Appel \& Muysken (1987: 159) use the processual term 'resyntactization', but it is unclear whether this is intended to denote the replacement of single constructions or system-wide restructuring.

Weinreich (1953: 30-31), and many others since, uses the term 'interference', but he applies it to contact-induced effects of all kinds. Clyne (1967: 18-19) abandons the term because of its different uses by different scholars and others have avoided it because non-technical senses of 'interference' give it an evaluative overtone (Heine \& Kuteva 2005: 34).

Gumperz \& Wilson (1971), Sasse (1985), Aikhenvald (2002) and Johanson (2003) all use the term 'convergence'. The everyday meanings of the word imply reciprocity, i.e. that two languages become simultaneously more like each other. However, languages in contact do not typically each become more like the other. Instead, one language undergoes contact-induced change on the model of another. ${ }^{13}$ Johanson (2003: 4) says that for him, 'convergence' may result from either 'unilateral influence' or 'bilateral influence'. Where the change is unilateral, 'convergence' seems to me to be a rather odd term. It is also used to cover lexicon, morphology and/or phonology as well as syntax. ${ }^{14}$

Thomason \& Kaufman (1988: 83-97) discuss the fact that 'structural borrowing', i.e. metatypy, involving a number of contiguous languages leads to the formation of a Sprachbund or 'linguistic

${ }^{11}$ Heine \& Kuteva (2005: 6) use 'borrowing' only for inter-language transfers that include the transfer of phonological form.

${ }^{12}$ Almost as an afterthought Gołąb coins 'isosemantism' for a lexical calque.

${ }^{13} \mathrm{I}$ am not of course claiming that convergence does not occur, but rather that, if it does occur, it is the outcoming of separate processes affecting each language. For sociolinguistic reasons these processes are more likely to occur at different historical periods than simultaneously. The one piece of evidence of convergence at Kupwar is that the Marathi and Urdu varieties have both replaced Indo-Aryan grammatical gender with Kannada sex-based gender. Other changes are of Urdu and Kannada towards Marathi.

${ }^{14}$ A more appropriate context for the term 'convergence' is koineisation, where dialects or closely related languages spoken in a newly forged speech community become increasingly similar until a single common language emerges. 
area'. A question in the case of, say, the Balkan Sprachbund, is whether there has indeed been gradual convergence among its languages or a sequence of bilingual situations in which (unilateral) metatypy has occurred. This requires further investigation.

Johanson uses the term 'code-copying', which captures the point that speakers do not 'borrow' a construction: they imitate it. However, Johanson's definition (1998: 327-328, 2002: 287-288) makes it clear that 'code-copying' denotes the whole range of outcomes of contact-induced change, whether lexical borrowing, lexical or grammatical calquing, metatypy or language shift.

In a passage about Ross (2001) in his review of Aikhenvald \& Dixon (2001), Parkvall (2003: 653 ) describes metatypy as 'a concept closely related to (and near-synonymous with) "calquing" or "syntactic borrowing" or "regrammaticisation".' His confusion of metatypy with calquing is doubtless a result of the fact that I included calquing within metatypy in Ross (2001), but one would have to stretch the meaning of 'calquing' well beyond its normal linguistic usage to encompass syntactic restructuring. I have indicated above why I do not think 'syntactic borrowing' is an appropriate synonym for metatypy. The term 'regrammaticisation' is not familiar to me from the literature on contact. ${ }^{15}$

Heine \& Kuteva $(2003,2005)$ articulate a position different from any of the authors mentioned above, emphasising that many of the changes occurring in the course of grammatical calquing are effectively instances of grammaticisation. Among their many examples is the calquing of postpositions in Takia ( $(2)$. They point out that the process by which the relational nouns 'inside' and 'top' became postpositions in Takia is a grammaticisation process which enables Takia speakers to imitate a Waskia construction (2003: 536, 2005: 86-89). They do not, however, suggest that grammatical calquing is a form of grammaticisation, but rather that a calque may lead subsequently to a grammaticisation that more closely matches the construction in the model language. They also readily admit that the syntactic restructuring entailed in metatypy cannot always be accounted for by grammaticisation processes.

Inadvertently, Heine \& Kuteva raise a question which requires further research, and this concerns the role of speakers' consciousness in calquing, metatypy and grammaticisation. They describe contact-induced change in terms that suggest not only that speakers are conscious of what they are doing, but that their innovations are quite deliberate, as indicated by the phrases I have italicised in the sample below. In their account of replica grammaticisation, they write:

Speakers of language R[eplica] notice that in language M[odel] there is a grammatical category $\mathrm{Mx}$. They develop an equivalent category $\mathrm{Rx}$, using material available in their own language (R). To this end, they replicate a grammaticalization process they assume to have taken place in language M... (Heine \& Kuteva 2003: 539, Heine \& Kuteva 2005: 92).

These are unusual inferences, as linguists typically assume that speakers do not make conscious changes in their grammars. It is sometimes suggested that grammaticisation is teleological, in the sense that the need to fulfil a certain function causes the emergence of a grammaticisation pattern, but this does not presuppose a conscious choice by speakers. Recent research on the effects of frequency favours a non-teleological account of grammaticisation (Bybee 2005), whereby speakers innovate a way of fulfilling a function, and the new construction is automated as it increases in frequency and undergoes the processes that are labelled as grammaticisation (Haiman 1994, Hopper 1987, 1998).

It seems to me that one cannot reasonably argue that speakers consciously perform grammaticisation. It could perhaps be argued that the calquing process entails a degree of awareness, but I am inclined to believe that even calquing and metatypy are largely driven by effort-

\footnotetext{
15 According to Trask (2000: 278) 'regrammaticalisation' and 'regrammatisation' are sometimes used to denote 'the shift of a grammatical morpheme from one function to another': this can be a part of grammatical calquing or metatypy, but a rather small part only.
} 
reduction practices of which speakers are only marginally aware. I prefer to reformulate Heine and Kuteva's account as follows:

Speakers of language R[eplica] also control language M[odel]. They establish functional correspondences between the constructions of the two languages, and remodel the constructions of language $\mathrm{R}$ so that they more closely match those of language $\mathrm{M}$. This entails extending or narrowing the functional ranges of certain constructions in language $\mathrm{R}$ and/or adapting constructions in language $\mathrm{R}$ so that they more closely match those of language $\mathrm{M}$ in their constituents and perhaps also in their syntax. These adaptations may in turn lead to grammaticisation.

This reformulation is a general account of grammatical calquing and metatypy which appears to ignore the fact that Heine \& Kuteva are describing replica grammaticisation in particular here. Their account presupposes that speakers can analyse the grammaticisation process that has occurred in language M. My reformulation assumes that in the process of establishing functional correspondences between constructions in the two languages, speakers acquire a knowledge of the functions of the components of the constructions. If they identify a grammaticised component, then it is liable to be replicated.

The issue of awareness is an important one. If speakers are conscious of the differences between functionally equivalent constructions in the replica and model languages, then one might expect them to pick and choose their innovations. If, on the other hand, grammatical calquing and metatypy are powered by effort-reduction practices of which speakers are only barely aware, then we would expect these processes to operate at any point where there is a mismatch between the constructions of the two languages. This is the subject of the next section.

\section{A strong hypothesis}

As I commented in $\S 4$, the study of contact-induced morphosyntactic change has been adversely affected by the use of anecdotal examples which do not tell us about the effects of contact on the grammar of a language as a whole. When contact linguists follow this procedure, we cannot know whether contact-induced morphosyntactic change typically affects single constructions or whether it typically affects grammars as wholes, i.e. brings about metatypy.

The way forward, it seems to me, is to adopt a strong hypothesis based on the insights of Nadkarni, Sasse, Haase and Prince cited in $\S 4$. The hypothesis is that, by default, contact-induced morphosyntactic change in one of a bilingual community's languages entails the restructuring of the whole grammar on the model of the community's other language. That is, metatypy is the default, and the borrowing of single constructions a rarity that requires special explanation (Harris \& Campbell 1995:120-150).

Although I suspect that metatypy is more common than the literature has recognised, I put the strong hypothesis forward as a basis for research, not as a statement of belief. Clearly, it can only be tested by examining the histories of whole languages in bilingual situations, and this is demanding, but it is a rational way forward. At present, we simply do not have enough detailed studies of single languages.

I would expect such studies to reveal the factors which allow/cause metatypy, rather than just grammatical calquing, to occur (\$3.3). I would also expect such studies to show that in some instances where just one or two pieces of 'structural borrowing' have occurred, this reflects the fact that the remainder of the two grammatical systems already matched each other well, as in the Konkani/Kannada case $(\S 4)$.

Whole-language studies will also allow us to see whether metatypy falls into a predictable sequence of internal stages. From the examples we do have, it appears that the clause is restructured first, then the phrase and finally the word, although this sequence is rarely completed. Anêm, a Papuan language of New Britain, reflects restructuring of the clause only (on an Oceanic model; see 
Ross 2001 and references therein). Takia reflects restructuring of the clause and the phrase. The languages at Kupwar $(\S 1)$ apparently reflect reorganization of clause, phrase and word-internal morphemic structures. Outcomes which do not follow this sequence, e.g. the restructuring of the phrase but not the clause, have not so far been found. Metatypy has been described here as syntactic restructuring, but, as at Kupwar, syntax may also include the ordering of bound morphemes.

\section{Theoretical implications}

If Sasse and others are right that lexical calquing, grammatical calquing and metatypy are all driven by the need of bilingual speakers' to express the same thoughts in both their languages, this has certain implications for theory beyond the study of contact. The organisation of the lexicon and of morpheme paradigms (i.e. their semantic organisation), the composition and meaning of lexical collocations, and the syntax and functions of grammatical constructions are all affected by the drive for intertranslatability because they all encode meaning. When calquing and metatypy occur, these things change, in contrast to phonological forms, which (as I demonstrated for Takia and for Mixe Basque) remain the same unless lexical borrowing occurs.

Grace (1981: 5-6) seizes on the distinction between what changes and what remains unchanged when he writes,

...I have attempted to develop a view of the make-up of a language that assumes that its two main components are precisely those that separate out in contact situations, i.e., one component consisting of just those parts that are subject to convergent change and the other of just those parts that resist such change.

He names the meaning-based component content form and the phonological forms lexification (Grace 1981: 7, 24).

Introducing his revision of the architecture of language, Grace (1981: 23) quotes (Labov 1971: 460), who writes, "One can hardly doubt, after Gumperz' research, that the lexical components of a language can be divorced from the underlying grammatical sub-structure.' Labov speaks of the "notion that there are ... "dotted lines" in a language, and that one can tear out one component and throw it away ..." (459-460). However, Grace's inference is that for Labov the two components are the lexicon and the grammar, and he writes, "the validity of the grammar-lexicon model of languages is precisely one of the assumptions that is called into question by the dotted line phenomenon" (Grace 1981: 23). Instead, Grace continues, "I will argue that of the two components distinguished by the dotted line, the first consists of everything concerned in the conceptualization of the message while the second consists just in the forms of the actual words" (Grace 1981: 24). It is precisely because he rejects the grammar-lexicon model that Grace adopts the terms "content form' and 'lexification'.

In fact, Labov's position is perhaps nearer to Grace's than the latter thinks. Labov writes, "Gumperz finds that the two languages, Dravidian Kannada and Indo-European Marathi have become practically identical in their deep structure and semantics, on the one hand, and in their phonetic output on the other, whilst they have consistently remained distinct in lexicon and grammatical formatives" (Labov 1971: 460). Since Labov puts semantics with deep structure, separating 'lexicon' from it, it is a legitimate inference that what he meant by 'lexicon' was Grace's lexification, whilst his deep-structure-plus-semantics is conceptually similar to Grace's 'content form'.

Grace (1981: 24) further analyses content form into two components, content substance and (what I take to be) morphosyntactic structure. ${ }^{16}$ This is his only reference to 'content substance'. In Grace (1987) he talks instead of 'conceptual events' and 'conceptual elements'. As linguists, our construal of linguistic events tends to be so bound to the grammar-lexicon model and to views of

${ }^{16}$ Grace takes the terms 'content form' and 'content substance' from Hjelmslev (1961: 60-62). 
what is universal that we at first find content substance hard to conceptualise. An example which I used in a slightly different context in Ross (1996: 203-204) may help to clarify this. Speakers of various languages experiencing what is objectively presumably the same physical sensation will say:

(28) a. English:

I am cold

b. Buru: 'I (am) cold'

yako bridi-n

I cold-its

(29) a. Balinese: 'The body is cold'

dingin awak-é

cold body-the

(30) a. French: 'I have cold'

j'ai froid

I have cold

b. Dutch: 'I have it cold'

$i k$ heb het koud

I have it cold

(31) a. German: 'To me is cold'

mir ist kalt

me.DAT is cold

b. Russian: 'To me (is) cold'

mne xolodno

me.DAT cold.NEUT:S

(32) a. Tokelauan: 'I freeze'

ko au e makalili

TPC I PRES feel.cold

b. Norwegian:'I freeze'

jeg fryser

I freeze:PRES

(33) a. Takia: 'Cold hits me'

madid i-fin-ag-da

cold it-hit-me-IMPF

b. Lewo: 'Cold bites me'

miava kar-nu

cold bite-me

c. Koiari: 'Cold hits me'

ribiri-vare da vani-ma

cold-SPECR me hit-PRES

d. Korafe: 'Cold does me'

na yaura erira

me cold it.does

In Grace's terms, English and Buru (Austronesian, eastern Indonesia) in (28a) have the same content substance, with a proposition in which the property 'cold' is predicated of the first person singular pronoun ('I (am) cold'). In Balinese (Austronesian, central Indonesia) in (29a), there is a different content form, as the property is predicated of the body. In French in (30a) 'cold' is a nominal, and its possession is predicated of the first person singular pronoun ('I have cold'). I am not sure how to characterise the Dutch content substance of (30b). German and Russian in (31) are similar to English, but treat the first person singular pronoun as a recipient ('To me is cold'). 
Tokelauan (Austronesian, Polynesian) and Norwegian in (32) both predicate a verb of the first person singular pronoun ('I freeze'). Finally, Takia, Lewo (Austronesian, Central Vanuatu), Koiari and Korafe (Papuan, C. and S.E. Papua respectively) in (33) all conceive of cold as a force that affects the first person singular patient.

There are thus a number of different content substances expressing the 'same' notion. Significantly, similar content substance does not mean similar content form: English I am cold instantiates the English copula construction with a property predicate but Buru yako bridin instantiates an adjectival predicate without a copula. In other words, the two languages have (in this instance) similar content substance but different morphosyntax.

Grace's (1981) view of the architecture of language is summarised in (34).

(34) Grace's (1981) view of language

- lexification (phonological form)

- content form (semantic organisation of the lexicon and of morpheme paradigms, the composition and meaning of lexical collocations, and the syntax and functions of morphosyntactic constructions)

- content substance (the organisation of meaning: 'ways of saying things')

- morphosyntactic structure

As I noted in $\S 2$, lexical collocations ${ }^{17}$ are among the most dramatic witnesses to calquing. Interestingly, the grammar-lexicon model has nowhere to put them, ignoring the huge role that they obviously play in a language. A lexical collocation has a split personality in the grammar-lexicon model, belonging in the grammar in that it manifests a syntactic construction but in the lexicon insofar as it is semantically idiosyncratic. In Grace's model they are an important component of content form.

Grace's and Labov's observation that content form consists of what is replaced in language contact requires expansion. Content substance is what is replaced through (lexical and grammatical) calquing: bilingual speakers become more and more at home in one of their languages and the content substance of the other language is increasingly replaced by that of the model language. These changes may also bring about structural parallelisms between the two languages (§3.3), leading to further morphosyntactic adjustments which render the changing language more similar to the model language, so that their similarities are not just in content substance but in content form. This, of course, is metatypy.

I have adopted Grace's model and terminology here because he derives his model directly from calquing and metatypy. It is worthy of note, however, that others have arrived at a similar architecture by quite different routes. As I noted in Ross (2001: 148), Levelt's (1992) model of what happens when a person speaks matches Grace's. The decision to speak leads to 'lemma access', where lemmas are units of content substance. This is followed by morphosyntactic encoding, the outcome of which is a piece of content form. Finally comes phonological encoding, when lexification is added and the piece of speech is ready for utterance. Langacker's Cognitive Grammar also has an architecture which resembles Grace's. His 'semantic structures' are Grace's content substance, his 'symbolic structures' are morphosyntax, and his 'phonological structures' are Grace's lexification (Langacker 1991: 102-127).

These architectures represent among other things a return to the Saussurean sign as a pairing of form and meaning. Meaning is content substance, and the form-meaning pairing is content form.

${ }^{17}$ Speech formulas in Pawley's (2001: 238-240) terminology. 
Whilst most linguists recognise, at least pre-theoretically, that a word is a sign, architectures like Grace's and Langacker's remind us that lexical collocations and morphosyntactic constructions are also signs. ${ }^{18}$

\section{Summing up}

The primary point made in this paper is that metatypy as previously defined should be broken down into two phases, calquing and metatypy proper (i.e. syntactic restructuring). Although metatypy never occurs without calquing, calquing may certainly occur without metatypy. But when metatypy occurs, it is not easy to determine where calquing ends and metatypy begins.

My earlier definition of metatypy was also too narrowly defined in its social parameters. Not only the emblematic language of a speech community but also a lingua franca used heavily among members of a community may undergo calquing and metatypy.

Metatypy is thus not appropriately labelled 'structural borrowing' because it entails the imitation in the replica language of constructions in the model language. This imitation makes use of or builds on constructions that already exist in the replica language. Metatypy almost certainly consists of processes of which speakers are scarcely aware, and this suggests that speakers do not 'choose' certain constructions to 'borrow' but that metatypy is likely to occur across the board wherever there are differences in content form between the replica language ad the model language. This, however, is a hypothesis that needs to be tested.

Finally, calquing and metatypy are important not simply because they seem to occur frequently but because they imply that the conventional grammar-lexicon model of language architecture is an inadequate framework for the description of calquing and metatypy.

\section{References}

Aikhenvald, Alexandra Y. 2002. Language contact in Amazonia. Oxford: Oxford University Press.

Aikhenvald, Alexandra Y. 2003. Mechanisms of change in areal diffusion: new morphology and language contact. Journal of Linguistics 39: 1-29.

Aikhenvald, Alexandra Y. \& R.M.W. Dixon (eds.). 2001. Areal diffusion and genetic inheritance: problems in comparative linguistics. Oxford: Oxford University Press.

Appel, Rene, and Pieter Muysken. 1987. Language contact and bilingualism. London: Edward Arnold.

Bowden, John. 2005. Language contact and metatypic restructuring in the directional system of North Maluku Malay. Concentric: Studies in Linguistics 31: 133-158.

Breu, Walter. 2003a. Bilingualism and linguistic interference in the Slavic-Romance contact area of Molise (Southern Italy). Words in time: diachronic semantics from different points of view ed. by Regine Eckardt, Klaus von Heusinger \& Christoph Schwarze, 351-373. Berlin: Mouton de Gruyter.

Breu, Walter. 2003b. Impersonales Neutrum im Moliseslavischen. Rusistika - slavistika lingvistika. Festschrift für Werner Lehfeldt zum 60. Geburtstag ed. by Sebastian Kempgen,

\footnotetext{
${ }^{18}$ The recognition of constructions as signs is also characteristic of construction grammars, of which Croft's, borrowing heavily from Cognitive Grammar, is the version which comes closest in spirit to the architectures discussed here (2001, 2004: 225-290).
} 
Ulrich Schweier \& Tilman Berger, 57-71. München: Otto Sagner. (Die Welt der Slaven, Sammelbande Bd. 19).

Bybee, Joan L. 2005. The impact of use on representation: grammar is usage and usage is grammar. Unpublished ms.

Campbell, Lyle. 1987. Syntactic change in Pipil. International Journal of American Linguistics 53: 253-280.

Chappell, Hilary. 2001. Language contact and areal diffusion in Sinitic languages. Areal diffusion and genetic inheritance: problems in comparative linguistics ed. by Alexandra Y. Aikhenvald \& Robert M. W. Dixon, 328-357. Oxford: Oxford University Press.

Clyne, Michael. 1967. Transference and triggering. The Hague: Martinus Nijhoff.

Croft, William. 2001. Radical Construction Grammar: Syntactic theory in typological perspective. Oxford: Oxford University Press.

Croft, William \& D. Alan Cruse, 2004. Cognitive linguistics. Cambridge: Cambridge University Press.

Denison, Norman, 1968. Sauris: a trilingual community in diatypic perspective. Man, New series 3: 578-592.

Denison, Norman. 1977. Language death or language suicide? International Journal of the Sociology of Language 12: 13-22.

Denison, Norman. 1988. Language contact and language norm. Folia Linguistica 22: 11-35.

D’Jernes, Lucille. 1990. Arop-Lokep grammar. Unublished ms, Summer Institute of Linguistics, Ukarumpa.

D’Jernes, Lucille. 2002. Arop-Lokep. The Oceanic languages ed. by John Lynch, Malcolm Ross \& Terry Crowley. Richmond: Curzon Press.

Drewes, A.J. 1994. Borrowing in Maltese. Mixed languages: 15 case studies in language intertwining ed. by Peter Bakker \& Maarten Mous, 83-111. Amsterdam: Institute for Functional Research into Language and Language Use (IFOTT).

Emeneau, Murray B. 1956. India as a linguistic area. Language 32: 3-16.

Emeneau, Murray B. 1962. Bilingualism and structural borrowing. Proceedings of the American Philosophical Society 106: 430-442.

Foley, William A. 1986. The Papuan languages of New Guinea. Cambridge: Cambridge University Press.

Gołąb, Zbigniew, 1959. Some Arumanian-Macedonian isogrammatisms and the social background of their development. Word 15: 415-435.

Grace, George W. 1981. An essay on language. Columbia, SC: Hornbeam.

Grace, George W. 1987. The linguistic construction of reality. London: Croom Helm.

Gumperz, John J. 1969. Communication in multilingual communities. Cognitive anthropology ed. by Stephen Tyler, New York: Holt, Rinehart and Winston. 
Gumperz, John J. \& Robert Wilson, 1971. Convergence and creolization: a case from the IndoAryan/Dravidian border. Pidginization and creolization of languages ed. by Dell Hymes, 151168. Cambridge: Cambridge University Press.

Haase, Martin. 1992. Sprachkontakt und Sprachwandel im Baskenland: Einflüsse des Gaskognischen und Franzosischen auf das Baskische. Hamburg: Buske.

Haiman, John. 1988. Rhaeto-Romance. The Romance languages ed. by Martin Harris \& Nigel Vincent, 351-390. London: Croom Helm.

Haiman, John. 1994. Ritualization and the development of language. Perspectives on grammaticisation ed. by William Pagliuca. Amsterdam: John Benjamins.

Harris, A. and Lyle Campbell. 1995. Historical Syntax in cross-linguistic perspective. Cambridge: Cambridge University Press

Heine, Bernd \& Tania Kuteva. 2003. On contact-induced grammaticalization. Studies in Language 27: 529-572.

Heine, Bernd \& Tania Kuteva. 2005. Language contact and grammatical change. Cambridge: Cambridge University Press.

Hepner, Mark. 1986. Bargam grammar essentials. Unpublished manuscript, Summer Institute of Linguistics, Ukarumpa.

Hjelmslev, Louis. 1961. Prologomena to a theory of language. $2^{\text {nd }}$ ed. Madison: University of Wisconsin Press.

Hopper, Paul J. 1987. Emergent grammar. Berkeley Linguistics Society 13: 139-157.

Hopper, Paul J. 1998. Emergent grammar. The new psychology of language: cognitive and functional approaches to linguistic structure ed. by Michael Tomasello, 155-175. Mahwah, N.J.: Lawrence Erlbaum Associates.

Johanson, Lars. 1998. Code-copying in Irano-Turkic. Language Sciences 20: 325-337.

Johanson, Lars. 2002. Contact-induced change in a code-copying framework. Language change: the interplay of internal, external and extra-linguistic factors ed. by Mari C. Jones \& Edith Esch, 285-313. Berlin: Mouton de Gruyter.

Johanson, Lars. 2003. Converging codes in Iranian, Semitic and Turkic. Linguistic convergence and areal diffusion: case studies from Iranian, Semitic and Turkic ed. by Eva A. Csato, Bo Isaksson \& Carina Jahani, 1-29. London: Routledge Curzon.

Jones, Mari C. 2002. Mette a haout dauve la grippe des angllais: convergence on the Island of Guernsey. Language change: the interplay of internal, external and extra-linguistic factors ed. by Mari C. Jones \& Edith Esch, 143-168. Berlin: Mouton de Gruyter.

King, Ruth. 2000. The lexical basis of grammatical borrowing: a Prince Edward Island French case study. Amsterdam: John Benjamins.

Labov, William. 1971. The notion of 'system' in creole studies. Pidginization and creolization of languages ed. by Dell Hymes, 447-472. Cambridge: Cambridge University Press.

Langacker, Ronald W. 1991. Concept, image and symbol: the cognitive basis of grammar. Berlin: Mouton de Gruyter. 
Levelt, Willem J.M. 1992. Accessing words in speech production: stages, processes and representations'. Cognition 42: 1-22.

Lorimer, David L.R. 1937. Burushaski and its alien neighbours: problems in linguistic contagion. Transactions of the Philological Society, 63-98.

Nadkarni, Mangesh V. 1975. Bilingualism and syntactic change in Konkani. Language 51: 672683.

Parkvall, Mikael. 2003. Review of Aikhenvald \& Dixon (2001). Journal of Linguistics 39: 652-657.

Pawley, Andrew. 2001. Review article: Phraseology, linguistics and the dictionary. International Journal of Lexicography, 14:122-134.

Platt, John T. 1975. The Singapore English speech continuum. Anthropological Linguistics 17: 363374.

Prince, Ellen F. 1998. The borrowing of meaning as a cause of internal syntactic change. Historical linguistics 1997: Selected papers from the 13th International Conference on Historical Linguistics, Dusseldorf, 10-17 August 1997 ed. by Monika S. Schmid, Jennifer, R. Austin \& Dieter Stein, 339-362. Amsterdam: John Benjamins.

Ross, Malcolm. 1987. A contact-induced morphosyntactic change in the Bel languages of Papua New Guinea. A world of language: papers presented to Professor S.A. Wurm on his 65th birthday ed. by Donald C. Laycock \& Werner Winter, 583-601. Canberra: Pacific Linguistics.

Ross, Malcolm. 1988. Proto Oceanic and the Austronesian languages of western Melanesia. Canberra: Pacific Linguistics.

Ross, Malcolm. 1994a. Areal phonological features in north central New Ireland. Language contact and change in the Austronesian world ed. by Thomas E. Dutton \& Darrell Tryon, 551-572. Berlin: Mouton de Gruyter.

Ross, Malcolm. 1994b. Describing inter-clausal relations in Takia. Topics in descriptive Austronesian linguistics ed. by Ger P. Reesink, 40-85. Leiden: Vakgroep Talen en Culturen van Zuidoost-Azie en Oceanie, Rijksuniversiteit te Leiden.

Ross, Malcolm. 1996. Contact-induced change and the comparative method: cases from Papua New Guinea. The comparative method reviewed: regularity and irregularity in language change ed. by Mark Durie \& Malcolm Ross, 180-217. New York: Oxford University Press.

Ross, Malcolm. 1997. Social networks and kinds of speech-community event. Archaeology and language ed. by Roger M. Blench \& Matthew Spriggs, 209-261. London: Routledge.

Ross, Malcolm. 2001. Contact-induced change in Oceanic languages in north-west Melanesia. Areal diffusion and genetic inheritance: problems in comparative linguistics ed. by Robert M.W. Dixon \& Alexandra Y. Aikhenvald, 134-166. Oxford: Oxford University Press.

Ross, Malcolm. 2002. Takia. The Oceanic languages ed. by John Lynch, Malcolm Ross \& Terry Crowley, 216-248. Richmond: Curzon Press.

Ross, Malcolm. 2003a. Diagnosing prehistoric language contact. Motives for language change ed. by Raymond Hickey, 174-198. Cambridge: Cambridge University Press. 
Ross, Malcolm. 2003b. Talking about space: terms of location and direction. The lexicon of Proto Oceanic: The culture and environment of ancestral Oceanic society. 2: The physical world ed. by Malcolm Ross, Andrew Pawley \& Meredith Osmond, 221-284. Canberra: Pacific Linguistics.

Ross, Malcolm. 2006. Metatypy. Encyclopedia of language and linguistics ed. by Keith Brown, 9599. $2^{\text {nd }}$. Oxford: Elsevier.

Ross, Malcolm. Forthcoming. Two kinds of locative construction in Oceanic languages: a robust distinction. Linguistic description and linguistic applications: studies in memory of Terry Crowley ed. by John Lynch, Jeff Siegel \& Diane Eades, Amsterdam: John Benjamins.

Ross, Malcolm, with John Natu Paol. 1978. A Waskia grammar sketch and vocabulary. Canberra: Pacific Linguistics.

Sasse, Hans-Jurgen. 1985. Sprachkontakt und Sprachwandel: die Grazisierung der albanischen Mundarten Griechenlands. Papiere zur Linguistik 32: 37-95.

Sasse, Hans-Jurgen. 1990. Language decay and contact-induced change: similarities and differences. Arbeitspapier (Institut für Sprachwissenschaft, Universität zu Köln) 12 (Neue Folge): 30-56.

Soper, John. 1996. Loan syntax in Turkic and Iranian. Bloomington, Indiana: Eurolingua. (Revised and edited by Andras J.E. Bodrogligeti.)

Sridhar, Shikaripur N. 1978. Linguistic convergence: Indo-Aryanization of Dravidian languages. Studies in the Linguistic Sciences 8: 197-215.

Thomason, Sarah G. \& Terrence S. Kaufman. 1988. Language contact, creolization and genetic linguistics. Berkeley: University of California Press.

Trask, Robert Lawrence. 2000. The dictionary of historical and comparative linguistics. Edinburgh: Edinburgh University Press.

Waters, Bruce, Salme Tuominen \& Judy Rehburg. 1993. Takia: a Western Oceanic language of Papua New Guinea. Unpublished manuscript, Summer Institute of Linguistics, Ukarumpa (Papua New Guinea).

Weinreich, Uriel. 1963. Languages in contact. The Hague: Mouton. 